\title{
Tobacco harm to the developing child
}

\author{
Alain Braillon • Susan Bewley • Gérard Dubois
}

Received: 1 April 2010 /Accepted: 3 June 2010 /Published online: 11 June 2010

(C) Springer-Verlag 2010

In a recent correspondence, we expressed a view about labeling second-hand smoking as child maltreatment $[3,9]$. In fact, passive smoking endangers every step of development.

Beginning with fetal exposure, smoking during pregnancy is the most common avoidable cause of preterm birth, intrauterine growth retardation, and perinatal mortality in the Western world [12]. Harmful effects also include miscarriage, bleeding, placental abruption, and stillbirth though smoking may protect against preeclampsia [7]. France occupies a special niche among countries paying too little concern for this problem with the highest rate of pregnant smokers $(22 \%)$ in Europe $[4,5]$. In too many countries, health policies ignore the fact that cognitive-behavioral therapy (CBT) plus nicotine replacement therapy (NRT) is a cheap, effective and well-tolerated treatment during and outside pregnancy $[7,11]$.

After birth, newborn and child exposure to second-hand smoke implies breathing in thousands of toxic chemicals released both by the burning tip of the cigarettes ("sidestream") and by the smoker's exhalations. Nearly four fifths of the smoke that builds up in a room is the side-stream type. Exposure to second-hand smoke is more common as

\footnotetext{
A. Braillon $(\bowtie) \cdot G$. Dubois

Public Health, Northern Hospital,

80000 Amiens, France

e-mail: braillon.alain@gmail.com

S. Bewley

Womens Health Services,

Guys and St Thomas' Hospital NHS Foundation Trust,

London, UK
}

many mothers relapse after delivery and the father and other household members too may be smokers.

Children are especially vulnerable when exposed to second-hand smoke [14]. They have double the rate of respiratory disorders than children living in a smoke-free environment. Even if a child does not suffer from asthma but lives with parents who both smoke, he or she will show a $40 \%$ higher probability of having bronchitis, pneumonia, or bronchiolitis [10,14]. Learning and behavioral development may be impaired because of frequent absences from school. Lastly, children with smoking mother have double the risk of cot death. In the UK, the annual smoking-related burden is estimated as 20,000 cases of lower respiratory tract infection; 120,000 cases of middle ear disease; 22,000 new cases of wheeze and asthma; 200 cases of bacterial meningitis; and 40 sudden infant deaths (20\% of total) [14].

Despite many reports over the years, the disaster continues $[6,10,13,15]$. Tobacco companies have undermined and discredited the scientific consensus that passive smoking causes diseases (a three-judge panel of the Washington, DC, US Court of Appeals unanimously upheld a lower court ruling on May 22, 2009) yet doctors cannot let people ignore the fact that second-hand smoke is the most important indoor pollutant. No one would directly encourage child smoking, yet we do too little about the danger of second-hand tobacco smoke. Some notable exceptions have recently pointed the way; since June 1, 2007, it has become illegal in South Australia to smoke in a car with a child passenger (Amendment Act 2006. Section 48 of the Tobacco Products Regulation Act 1997). From 1 July 2009, in New South Wales the Public Health (Tobacco) Act 2008 creates a new offense of smoking in a car with a child under 16 years in the vehicle. A \$250 onthe-spot fine applies to the driver and any passenger who breaks the law. 
Pediatricians should not hesitate to label tobacco as the most frequent agent of child maltreatment despite the lack of intentionality of the child's carers. Smoking is a disease, a very powerful addiction, and an epidemic with devastating consequences. We must use truthful evidence, hold the tobacco industry accountable, and help rather than stigmatize parents. Healthcare providers and practitioners are not providing effective information, diagnosis, support, and treatment. It is reprehensible that social security schemes fail to reimburse treatments despite their cost effectiveness. Another exception is found in Belgium where pregnant women are offered a comprehensive package $(\mathrm{CBT}+\mathrm{NRT})$ that is also extended to smoking partners (Arrêté royal du $17 / 09 / 2005$ ). Reimbursement is critical for compliance as smoking and low socioeconomic status is correlated. However, smoking is a greater source of health inequality than social position [8]. A high percentage of women who do give up in early pregnancy relapse after delivery and this must also be a specific target of health promotion. Starting with the neonatal check-up at birth, advice and help for mothers and other family members must be planned to avoid postpartum relapse.

The last step is the early uptake of smoking by adolescents. Children growing up with parents or siblings who smoke are more likely to become smokers themselves [14]. It is predicted that 2 billion people will smoke in 2025 with most dramatic increases in low- and middle-income countries. Nowadays, in developed countries, one third of women of reproductive age smoke cigarettes. In the past decade, the proportion of heavy smokers has increased, particularly among women. Adults very rarely start smoking and more profitable results can be achieved by targeting the young rather than the elderly as customers. It is relatively easy to make cigarettes appear to be a cheap symbol of emancipation to otherwise sensible female adolescents. Numerous tobacco industry documents make clear that kids as young as 13 years are a key market audience with products and marketing campaigns developed especially for them [1]. Almost all new smokers are under 18 years; in New Zealand, the average age for starting to smoke is 14 years and a quarter of youth smokers start under 10 years [2].

Physicians can act effectively. Each step requires specific involvement and various skills. For example, mothers relapsing postpartum and the very addicted smoking father require different approaches. Smoking cessation could have been taught in medical curricula for over a decade. Pediatricians do not need to become tobacco cessation specialists but must help the smoking parents of their patients and a few tips are given in Box 1. Last but not least, pediatricians have a key role in lobbying for a smokefree society for children. One out of two smokers will die from a tobacco-related illnesses and children are their "replacement smokers". Tobacco companies rely on children taking up smoking to stay in business.
Box 1: A few tips
"Smoking is bad for you, as well as for your baby."
"If you smoke around your kids they smoke too."
"You can make your home and car smoke free zones."
"It is hard to give up smoking, and it can take many goes, so keep trying".
"Now would be a good time to quit. If you want I can help you to give up smoking."
"Even if you canno-t quit, you can ensure smoke free air for your child. What about limiting your
smoking at home to outdoors, or just one or two rooms where your children aren't allowed?"

Conflicts of interest GD has received consultation payments from Pfizer.

\section{References}

1. Anonymous. http://www.tobaccofreekids.org/reports/smokescreen/ marketingkids.shtml. Accessed 8 March 2010

2. Anonymous. http://protectourchildren.org.nz/. Accessed 20 April 2010

3. Braillon A, Bewley S, Dubois G (2010) Secondhand smoke is the most frequent cause of child maltreatment. Eur J Pediatr doi: 10.1007/s00431-010-1193-8
4. Braillon A, Bewley S (2010) Preventing prematurity is prosaic not enigmatic. N Engl J Med 362:2032

5. Braillon A, Lansac J, Delcroix M et al (2010) Tobacco and pregnancy: France always bad pupil. J Gynecol Obstet Biol Reprod (Paris) 39:1-2

6. Cheraghi M, Salvi S (2009) Environmental tobacco smoke and respiratory health in children. Eur J Pediatr 168:897-905

7. Einarson A, Riordan S (2009) Smoking in pregnancy and lactation: a review of risks and cessation strategies. Eur J Clin Pharmacol 65:325-330

8. Gruer L, Hart CL, Gordon DS, Watt GCM (2009) Effect of tobacco smoking on survival of men and women by social position: a 28-year cohort study. BMJ 338:b480 
9. Jud A, Lips U, Landolt MA (2010) Characteristics associated with maltreatment types in children referred to a hospital protection team. Eur J Pediatr 169:173-180

10. Palmieri M, Longobardi G, Napolitano G, Simonetti DM (1990) Parental smoking and asthma in childhood. Eur J Pediatr 149:738-740

11. Pollak KI, Oncken CA, Lipkus IM et al (2007) Nicotine replacement and behavioral therapy for smoking cessation in pregnancy. Am J Prev Med 33:297-305

12. Richardus JH, Graafmans WC, Verloove-Vanhorick SP et al (2003) Differences in perinatal mortality and suboptimal care between 10 European regions: results of an international audit. BJOG 110:97-105
13. Schellscheidt J, Jorch G, Menke J (1998) Effects of heavy maternal smoking on intrauterine growth patterns in sudden infant death victims and surviving infants. Eur $\mathrm{J}$ Pediatr 157:246-251

14. Tobacco Advisory Group of the Royal College of Physicians (2010) Passive smoking and children. http://www.rcplondon.ac. uk/professional-Issues/Public-Health/Pages/Tobacco.aspx. Accessed 26 March 2010

15. von Linstow ML, Høgh M, Nordbø SA et al (2008) A community study of clinical traits and risk factors for human metapneumovirus and respiratory syncytial virus infection during the first year of life. Eur J Pediatr 167:1125-1133 